\title{
An Assessment of Corruption's Impact on the Inflow of Foreign Direct Investment (in the Case of Georgia, Armenia and Azerbaijan)
}

\begin{abstract}
The aim of this paper is to investigate the impact of corruption on the inflow of foreign direct investment (FDI) in Georgia, Armenia and Azerbaijan, from 2012 to 2018. The study attempts to answer the question: "What effect does corruption have upon the level of foreign direct investment inflow to a country?" Using the data from UNCTAD for foreign direct investment and Corruption Perception Index from Transparency International, for a period of 7 years, 2012-2018, we evaluated the specific impact of corruptions on FDI using GDP as control variable. A regression model was developed to establish the relationship between FDI and Corruption Perception Index. Co-integrating Regression analysis was carried out using relevant econometric techniques. The model is based on a theoretical approach found in academic literature This exploratory paper results confirm the majority of literature and show a negative significant relation between the variables analysed but at a lower intensity than expected. Keywords: Foreign Direct Investment (FDI), Corruption Perception Index (CPI), Gross domestic product (GDP), Corruption
\end{abstract}

\section{Introduction}

In the modern time, in the growth dynamics of host countries FDI inflow plays a significant role. FDI can provide foreign currency for investment and foreign capital, generate domestic investment in matching funds, facilitate the transfer of managerial skills and technological knowledge, create modern job opportunities, increase local market competition, increase global market access for export commodities, etc. "The increasingly significant role played by FDI in the growth dynamics of emerging economies has created considerable research interest among development econ- 
omists A sizeable empirical literature has evolved on the determinants of FDI. Most empirical studies have generally identified the domestic economic environment, market size, infrastructure, human capital, economic openness, return on capital, political stability, etc. among the key determinants of FDI"1.

Corruption has recently emerged as one of the factors that affect FDI in the host country. The effects of corruption on economic activities have received attention in recent literature.

Theoretically, corruption can act as either a grabbing hand by raising uncertainty and transaction costs, which should impede FDI, or a helping hand by "greasing" the wheels of commerce in the presence of a weak regulatory framework, which should facilitate $\mathrm{FDI}^{2}$. Thus, mainly, there are two theories on how corruption affects FDI, which are the grabbing hand theory that indicates that corruption produced uncertainties and deterred foreign investors from entering the host country and the helping hand theory that indicates that corruption helps to reduce the red tape in the host country and increase the FDI in the host country. The level of corruption in the host country has been introduced as one factor among the determinants of FDI location ${ }^{3}$.

Results found in the empirical literature can be described as "mixed", as several studies found results supporting the grabbing hand hypothesis, i.e. corruption reduces FDI, just as several other studies found the opposite results that support the helping hand hypothesis, i.e. corruption facilitates FDI, and a few studies found no evidence to support either hypothesis.

Generally, corruption affects the investment attractiveness of the country, but it is not the major factor affecting the FDI inflow. First of all, investments go into the countries with an attractive, transparent and open economy, with low levels of corruption. The reason is that then for investors it is easier to make the decision about an investment and to calculate the profitability of the project. This is confirmed by such countries as the USA, UK, Canada, Australia and others. However, the Kohonen map shows that the leading positions are occupied by the countries with high level of corruption, as well as foreign direct investment, such as China, Brazil, India, which enter in the top ten highly invested countries, and also Russia, which came down to 16th position due to economic sanctions. Wide markets, low labour costs, an extensive banking network, wealth of natural resources, access to warm seas - all these factors increase the investment attractiveness of BRIC countries and outweigh the corruption costs. Also, BRIC countries have the most similarities in the type and stage of the economy and have similar government systems; hence, corruption in these coun-

R.M. Quazi, Corruption and Foreign Direct Investment in East Asia and South Asia: An Econometric Study, "International Journal of Economics and Financial Issues" 2014, vol. 4, no. 2, p. 231-242.

2 Ibidem, p. 231-242.

3 Ali Al-Sadig, The effects of corruption on FDI inflows, "The Cato Journal" 2009, vol. 29, no. 2. 
An Assessment of Corruption's Impact on the Inflow of Foreign Direct Investment...

tries has common roots - it is controlled and predictable. So, the investors, working in these countries, have an opportunity to account the corruption costs in business projects.

\section{Literature review}

"Corruption is not a new phenomenon; its history predates the dawn of modern civilization. In an interesting study of the history of corruption, Noonan (1984) has documented four millennia of history of bribes and corruption in many cultures. Due to the various forms that corruption can take, including practices such as bribery, extortion, influence, fraud, and embezzlement, corruption has been defined in different ways. Yet, since we are concerned only with corruption that affects the costs of investment operations, we use Macrae's ${ }^{4}$ 679) definition" ${ }^{\prime \prime}$. He defines corruption as an "arrangement" that involves "a private exchange between two parties (the 'demander' and the 'supplier'), which (1) has an influence on the allocation of resources either immediately or in the future, and (2) involves the use or abuse of public or collective responsibility for private ends." The demanders in our case may be the public officials and the suppliers are foreign investors. Many researchers say that the investment attractiveness of the country depends on the level of corruption both in private and public sectors. Corruption includes bribery and any other behaviours of persons, having the responsibility in the public or private sector, which violate their duties in order to obtain any improper advantage for themselves. Most authors consider corruption as an illegal tax, a barrier for the entrance of new participants, as well as undermining the legitimacy of the state and its ability to provide services of its institutions that support the proper functioning of economy spheres.

While there are many different definitions in the theoretical literature, definitions of corruption by Transparency International (TI) and the World Bank (WB) are the most sought-after. The WB defines corruption as "the abuse of public power for private gain", and the definition of corruption by TI is as follows: "the abuse of entrusted power for private gain" (www.transparency.org, 2017). Though corruption is mostly observed in the form of bribery, it also involves activities such as extortion, fraud, embezzlement, nepotism, cronyism, influence peddling, rent-seeking, money-laundering, and kickbacks ${ }^{6}$. According to Amundsen, corruption is a disease that destroys the functioning of vital organs by negatively affecting the social, political, cultural, and economic structure of a society. This is because it weakens the quality of

4 J. Macrae, Underdevelopment and the Economics of Corruption: A Game Theory Approach, "World Development" 1982, vol. 10, no. 8 p. 679.

5 R.M. Quazi, op. cit., p. 231-242.

6 J. Balboa, M. E. Medalla, Anti-Corruption and Governance: The Philippine Experience. APEC Study Center Consortium Conference 2006, 1-28, Ho Chi Minh City, Viet Nam, p. 1. 
governance and the efficiency of public policies, destroys the efficient distribution of resources, prevents the development of the private sector ${ }^{7}$. With a similar approach, the WB notes that corruption is one of the biggest obstacles to economic and social development because it undermines the rule of law and weakens the institutional foundation on which economic growth is based ${ }^{8}$. Because of these effects, the causes and consequences of corruption are one of the main concerns of policy makers and economists. Many researchers say that the investment attractiveness of the country depends on the level of corruption both in private and public sectors.

The theoretical literature on the effect of corruption on investment decisions of foreign investors contains two opposing views: the grabbing-hand theory of corruption and the helping-hand theory of corruption.

The grabbing-hand theory, which posits a negative relationship between corruption and FDI, addresses the issue based on the concept of cost. According to the theory, the necessity to bribe to get privileged access to markets, obtain government permits and licenses, or win profitable foreign contracts creates an extra cost to foreign investors. In this way, just like a tax, corruption decreases the expected return/ profit of an investment project by increasing the cost of doing business, disrupting the allocation of resources, and creating ambiguity, thus deterring foreign investors, whose main goal is to gain profit, and decreasing FDI inflows. Moreover, corruption negatively affects the other determinants of FDI, such as economic growth, productivity of public investment, and quality of infrastructure, having an indirect negative effect on FDI inflows ${ }^{9}$. On the other hand, some argue that corruption does not definitely reduce FDI inflows. This argument is based on the fact that some developed and developing countries known to have high levels of corruption also attract a high amount of FDI. "For instance, Habib and Zurawicki ${ }^{10}$ and Teixeira and Guimarães ${ }^{11}$ report that Mexico, Brazil, Indonesia, Italy, Poland, Russia, China, Thailand, Argentina, Malaysia, Belgium, and India have attracted high amounts of FDI in recent years despite high levels of corruption. This situation, where corruption is considered as

I. Amundsen, Political Corruption: An Introduction to the Issues,. Chr. Michelsen Institute Development Studies and Human Rights, Working Paper, 1999, p. 1.

8 Worldbank (2017), Combating Fraud and Corruption, www.ifc.org/wps/wcm/connect/Topics ExtContent/IFCExternal CorporateSite/ACHome (10.11.2019).

9 A. Al-Sadiq, The Effects of Corruption on FDI Inflows, "Cato Journal" 2009, vol. 29, no. 2, p. 267269; M.A. Alemu, Effects of Corruption on FDI Inflow in Asian Economies, "Seoul Journal of Economics" 2012, vol. 25, no. 4, p. 389-390; C. Castro and P. Nunes, Does Corruption Inhibit Foreign Direct Investment?. "Revista de Ciencia Politica" 2013, vol. 51, no. 1, p. 62; R. Quazi, V. Vemuri and M. Soliman, Impact of Corruption on Foreign Direct Investment in Africa, "International Business Research" 2014, vol. 7, no. 4, p. 232.

10 M. Habib, L. Zurawicki, Corruption and Foreign Direct Investment, "Journal of International Business Studies" 2002, vol. 33, no. 2.

11 C.A.A. Teixeira, L. Guimarães, Corruption and FDI: Does the Use of Distinct Proxies for Corruption Matter?, "Journal of African Business" 2015, vol. 16, no. 1-2. 
An Assessment of Corruption's Impact on the Inflow of Foreign Direct Investment...

a factor encouraging FDI inflows rather than reducing them, is explained by the helping-hand theory of corruption. According to this theory, corruption can be an effective "lubricant," especially in countries with a weak institutional structure and rigid red tape ${ }^{12}$. To put it more clearly, corruption activities, such as bribery, nepotism, etc., function as "speed money," thus relieving investors from burdensome government regulations and bureaucratic barriers and helping them get the job done more quickly"13. In this way, MNEs can capture financial benefits from the host countries that cannot be obtained through export, such as profitable contracts with the government, subsidies, permits and licenses, and tax incentives. This situation, which is extremely profitable for MNEs that obtain almost monopoly power in the host country, provides a great incentive for MNEs to bribe host government officials. Therefore, this theory argues that countries with high corruption are more preferred by $\mathrm{MNEs}^{14}$.

The World Bank studies show that corruption significantly reduces the volume of domestic and foreign investment. Looking at corruption as a kind of "tax" on business, they believe that every increase of this "tax" by $1 \%$ reduces the inflow of direct investment into the country by 5\%. Joseph S. Brada conducted a study using data of FDI in 49 donor countries and 167 host countries in 2005- 2009 years. The results showed that the corruption of the host countries has a negative impact on the volume of FDI inflows. Daniel F. Runde ${ }^{15}$ used data of 48 countries from 1998 to 2014 in order to determine the relationship between FDI and corruption. The results showed that corruption is a statistically significant variable and has a negative impact on the investments inflow. He argues that the $1 \%$ decrease of corruption level can lead to the approximately $10 \%$ increase of FDI inflow into the country. Cuervo-Cazurra ${ }^{16}$ analysed the inflow of foreign investment in 106 host countries. His research also has shown that corruption has a negative impact on the investment inflow. In this work it is also highlighted that investors from OECD member countries with a high level of corruption are not afraid to invest in countries with high levels of corruption. This is due to the fact that these investors already have the skills to work with corrupt officials, so the mechanisms of doing business in such an environment are well known for them. Dahlström and Johnson ${ }^{17}$ conclude that corruption has a negative impact on the inflow of foreign direct investment in developing countries. Also, many econ-

$12 \quad$ M.R. Quazi, op.cit., p. 231.

13 Ibidem, p. 641.

14 T. Kendall, Y. Zhou, The Impact of Corruption on FDI 2009, https://editorialex press.com/cgibin/ conference/download.cgi?db_name=serc2009\&paper_id=212, p. 3 (12.11.2019).

15 D.F. Runde, The cost of corruption, 2014 https://csis-prod.s3.amazonaws.com/s3fs- public/legacy_files/files/publication/140204_Hameed_CostsOfCorruption_Web.pdf (12.11.2019).

16 A. Cuervo-Cazurra, Who Cares about Corruption?, "Journal of International Business Studies" 2006, vol. 37, no. 6 .

17 T. Dahlström, A. Johnson, Bureaucratic Corruption, MNEs and FDI "Jönköping International Business School (JIBS)" 2007, no. 82. 
omists as Alemu, Woo, and Aparna found that corruption discourages investment. The conclusion is made that the reduction of the corruption level at $1 \%$ can lead to an increase of FDI inflows in emerging economies at 9\%.

All these researchers have concluded that corruption undermines economic freedom, by introducing the insecurity and uncertainty in economic relations which are the reasons for a decrease in FDI inflows. However, these scientists did not pay special attention to the countries that were exceptions and did not analyse the reasons why these countries fell out of the generally accepted rules. The aim of this paper is an assessment the impact of corruption on FDI inflows, as well as determining the countries which are exceptions from the common rule.

Foreign Direct Investments - Benchmark condition for the calculation of FDI is important in ensuring transparency in comparing international direct investment flows / values.

Benchmark condition for the calculation of FDI (according to Jones \&Wren ${ }^{18}$ ). Foreign Direct Investments $=$ Retained earnings (i.e. direct investors share of earnings/ losses) + Direct investors purchase less sales of enterprises' shares + Net increase in long and short term loans, credit and other amounts given by the direct investor to overseas enterprise - Overseas enterprise borrowing of money from the host country or from their own resources in order to give to the direct investor in the home country.

Types of FDI:

1. Greenfield refers to the establishment of companies - Greenfield investment;

2. Mergers and acquisitions: full or partial takeover of companies by foreign investors;

3. Business development: increasing FDI holdings in companies - foreign direct investment;

4. Firm restructuring: through capital injection (equity) financing losses of direct investment enterprises by foreign direct investors. (BNR Statistics 2013, p. 6).

FDI effects:

A) Direct effects (employment, commercial transactions growth, capital formation);

B) Indirect effects (transfer of technology and managerial skills to local firms);

C) Horizontal effects = horizontal spillovers (within the industry)

Positive (diffusion of technology within the industry by: - job reallocation - imitation process - entry of international firms specialized in related services);

18 J. Jones, C. Wren, Foreign Direct Investment and the Regional Economy, Ashgate Publishing, Ltd. 2012, p. 9. 
An Assessment of Corruption's Impact on the Inflow of Foreign Direct Investment...

Negative: competition or effect of "stealing market" (market / business stealing effect).

D) Vertical effects $=$ vertical spillovers (between industries - organizing vertical supply chain):

- Upstream chain: local firms are suppliers of inputs for foreign companies (a positive effect due to increased demand for inputs for local businesses and could lead to a reduction in average costs);

- Downstream chain: foreign companies are suppliers of inputs for local firms (it is also a positive effect).

Corruption Index - The Corruption Index is a Perception Index used to classify countries by their level of abuse of power for private gain among Governmental Institutions and the integrity of people in a position of authority. The Corruption Perception Index (CPI) provides a metric regarding the perceived levels of corruption by country and is available for 180 countries $^{19}$.

Categories of corruption:

- Systematic corruption (high level Institutionalized corruption as social corruption that modifies national Laws, Legislative Norms in favour of specific private firms);

- Instrumental corruption ("big corruption" that happens and could affect a given social Institution and/or an entire economic sector);

- Incidental corruption (individual "small corruption" that does not affect the majority of people from a country).

\section{Methodology}

To test issues related to FDI and corruption, one needs sound data concepts for the purpose at hand, an empirical dynamic FDI model, and an econometric approach devoid of important inconsistencies that can bias results when dealing with panel data.

Data variables - FDI inflows are drawn from UNCTAD database for 3 countries Georgia, Azerbaijan and Armenia. We also use as a control variable the real GDP for the countries analysed. In the examination of corruption, the most used measure is the Corruptions Perceptions Index (CPI) reported annually by Transparency International. This non-governmental organization has studied corruption since 1995 looking to draw attention to the damage caused by corruption and to stimulate gov-

19 https://www.georgianjournal.ge/politics/35501-corruption-perceptions-index-2018-georgias-got-58-out-of-100.html (10.11.2019). 
ernments to adopt and implement anti-corruption regulations ${ }^{20}$. "The Corruption Perceptions Index, Transparency International's flagship research product, has become the leading global indicator of public sector corruption. The index offers an annual snapshot of the relative degree of corruption by ranking countries and territories from all over the globe. In 2012, Transparency International revised the methodology used to construct the index to allow for comparison of scores from one year to the next. The 2018 CPI draws on 13 surveys and expert assessments to measure public sector corruption in 180 countries and territories, giving each a score from zero (highly corrupt) to 100 (very clean)"21.

Table 1 shows the variables used in our analysis.

Table 1. Description of the variables

\begin{tabular}{|c|c|c|c|}
\hline Measure & Data Source(s) & Calculation & Observed \\
\hline FDI & $\begin{array}{l}\text { Foreign direct investment: Inward and out- } \\
\text { ward flows and stock in millions USD }\end{array}$ & $\log$ FDI & $2017-2018$ \\
\hline CPI & $\begin{array}{l}\text { Transparency International draws on } 13 \\
\text { data sources from } 11 \text { globally dispersed in- } \\
\text { stitutions for this index. It ranges from } 0 \text { to } \\
\text { 100, with high values indicating absence of } \\
\text { corruption. }\end{array}$ & $\begin{array}{l}\text { The CPI is a composite index using data } \\
\text { compiled or published between } 2017 \text { and } \\
2018 \text { for the } 2018 \text { measure. Specifically, it } \\
\text { is computed as an un weighted average of } \\
\text { all estimates for a particular country. Cur- } \\
\text { rently, } 180 \text { countries are assessed. }\end{array}$ & $2017-2018$ \\
\hline DDP & UNCTAD database & real GDP in billions US dollars & 2017-2018 \\
\hline
\end{tabular}

The present article analysed the Foreign Direct Investments inflows in Georgia, Azerbaijan and Armenia, with GDP and Corruption Perception Index. The main data were gathered from Transparency International, UNCTAD Organizations, data published online, for the period 2012 - 2018. Based on theoretical and empirical research we wanted to see if there was a connection between Corruption Perception Index and FDI inflows. Table 2 presented below is compared based on changes reflected through years $2012-2018$.

Table 2. The evolution of FDI, CPI and GDP for Georgia, Azerbaijan and Armenia

\begin{tabular}{|c|c|c|c|c|c|c|c|c|c|}
\hline & \multicolumn{3}{|c|}{ Georgia } & \multicolumn{3}{|c|}{ Azerbaijan } & \multicolumn{3}{|c|}{ Armenia } \\
\hline & $\begin{array}{c}\text { FDI (USD } \\
\text { million) }\end{array}$ & CPI (score) & $\begin{array}{l}\text { GDP (USD } \\
\text { billion) }\end{array}$ & $\begin{array}{c}\text { FDI (USD } \\
\text { million) }\end{array}$ & CPI (score) & $\begin{array}{l}\text { GDP (USD } \\
\text { billion) }\end{array}$ & $\begin{array}{c}\text { FDI (USD } \\
\text { million) }\end{array}$ & CPI (score) & $\begin{array}{l}\text { GDP (USD } \\
\text { billion) }\end{array}$ \\
\hline 2012 & 1023 & 52 & 15.5 & 2005 & 27 & 69.6 & 497 & 34 & 10.62 \\
\hline 2013 & 1021 & 49 & 16.14 & 2632 & 28 & 74.16 & 346 & 36 & 11.12 \\
\hline
\end{tabular}

20 C.M. Amarandei, Corruption and Foreign Direct Investment. Evidence from Central and Eastern European States, http://www.ceswp.uaic.ro/articles/CESWP2013_V3_AMA.pdf (14.11.2019).

21 https://www.georgianjournal.ge/politics/35501-corruption-perceptions-index-2018-georgias-got-58-out-of-100.html (10.11.2019). 
An Assessment of Corruption's Impact on the Inflow of Foreign Direct Investment...

\begin{tabular}{||c|c|c|c|c|c|c|c|c|c||}
\hline 2014 & 1818 & 52 & 16.51 & 4430 & 29 & 75.24 & 404 & 37 & 11.61 \\
\hline 2015 & 1653 & 52 & 13.99 & 4048 & 29 & 53.07 & 17 & 35 & 10.55 \\
\hline 2016 & 1566 & 57 & 14.3 & 4500 & 30 & 37.7 & 33 & 33 & 10.55 \\
\hline 2017 & 1894 & 56 & 15 & 2867 & 31 & 40.7 & 250 & 35 & 11.53 \\
\hline 2018 & 1232 & 58 & 16.21 & 1403 & 25 & 46.94 & 254 & 35 & 12.43 \\
\hline
\end{tabular}

Source: UNCTAD and Transparency International.

The Ranking in Table 1 is based upon studies about corruption in 180 countries between 2012-2018. Georgia is just above the medium score with approx. 55 points out of 100, for the time period $2012-2018$, and the lowest score and most corrupt country is, Azerbaijan (29 out of 100,). During the time period $2012-2018$ there are no big changes in the score given to countries for corruption level within their economies and institutions.

When comparing Table 2 in the case of Georgia, within the time period 2012 2018, in search of a connection between Corruption Perception Index and FDI inflow, we see that Georgia is being perceived as a medium corrupt country (scores changing very little from 2012 to 2018) but with an impact on FDI inflows. As the country is perceived as more corrupt and the Corruption index gets lower, FDI inflows decreased from 2012 to 2013. There is a little discrepancy in 2018 when although the country gets a corruption score lower than the year before, 2017, the amount of FDI inflows increases. We may assume that the difference in corruption score from 52 in 2012 with a FDI inflow of 1023 million dollars, to 58 corruption score in 2018, with a 1232 million dollars FDI inflow, was not an "alarm trigger" for foreign investors, Georgia being a country with a medium level of corruption. Azerbaijan does not follow the trend of Georgia, in 2018 registering the lowest corruption score for the country ( 25 corruption score), the amount of FDI inflows for 2016 surpassing the 2017 amounts of FDI inflows, when Azerbaijan was perceived less corrupt than the year before (in 2016 - 14500 million dollars FDI inflows, 2017 - 2867 million dollars FDI inflows). In the case of Azerbaijan, there is not a connection between the Corruption Perception Index and the amount of FDI inflows received by the country from 2012 to 2018. Also, Armenia obtains a better total of FDI inflows from 2012 to 2014. Therefore, analysing the tables it can be concluded that there is no correlation or strong connection between a countries ' perceived corruption and investment inflows to that country, these facts sustaining the opinion of some researchers about the influence and impact of only corruption on the volume of FDI flows in a country. 


\section{Econometric Analysis}

The model is based on a theoretical approach found in academic literature. We use control variables such as GDP, in order to isolate the effect of corruption on foreign direct investment.

$F D I i, t=\alpha+\beta 1 C P I i, t-1+\beta 2 G D P i, t-1+\varepsilon i, t$

Where: $\boldsymbol{i}$ - the country subscript,

$\boldsymbol{t}$ - the time subscript,

$\boldsymbol{\beta} \boldsymbol{n}$ - unknown parameters to be estimated,

$\boldsymbol{\varepsilon} \boldsymbol{i}$, - the usual random disturbance term.

Taking into account, those decisions to invest abroad take time and in order to avoid simultaneity with the dependent variable, all independent variables are lagged one year.

\section{Results and interpretation}

Our analysis uses the multivariate regression technique. According to the Correlations table, the results show that between foreign direct investment and the perceived corruption is a negative significant relation, respectively a rise in the perception of corruption for the countries analysed deter the expected inflows of FDI for the next years. Also, it can be noticed a moderate direct relation between market potential and foreign direct investment received by the Georgia, Azerbaijan and Armenia.

Table 3 shows that the model chosen for our analysis is significant $(. S i g<.005)$ and adequate.

Table 3. Correlations Matrix

\begin{tabular}{|c|c|c|c|c|}
\hline & & FDI & CPI & GDP \\
\hline \multirow{3}{*}{ Pearson Correlation } & FDI & 1.002 & -.386 & .747 \\
\hline & CPI & -.386 & 1.002 & -.109 \\
\hline & GDP & .747 & -.109 & 1.002 \\
\hline \multirow{3}{*}{ Sig. (1-tailed) } & FDI & & .001 & .000 \\
\hline & CPI & .001 & . & .125 \\
\hline & GDP & .000 & .125 & \\
\hline \multirow{3}{*}{$\mathrm{N}$} & FDI & 120 & 120 & 120 \\
\hline & CPI & 120 & 120 & 120 \\
\hline & GDP & 120 & 120 & 120 \\
\hline
\end{tabular}

Source: author calculations using SPSS 20. 
An Assessment of Corruption's Impact on the Inflow of Foreign Direct Investment...

Table 4. Model Summary

\begin{tabular}{|c|c|c|c|c|c|c|c|c|c|}
\hline \multirow[b]{2}{*}{ Model } & \multirow[b]{2}{*}{$\mathrm{R}$} & \multirow[b]{2}{*}{ R Square } & \multirow[b]{2}{*}{$\begin{array}{l}\text { Adjusted } \\
\text { R Square }\end{array}$} & \multirow{2}{*}{$\begin{array}{l}\text { Std. Error } \\
\text { of the } \\
\text { Estimate }\end{array}$} & \multicolumn{5}{|c|}{ Change Statistics } \\
\hline & & & & & $\begin{array}{c}\mathrm{R} \\
\text { Square } \\
\text { Change }\end{array}$ & $\begin{array}{c}\text { F } \\
\text { Change }\end{array}$ & df1 & $\mathrm{d} f 2$ & $\begin{array}{c}\text { Sig. F } \\
\text { Change }\end{array}$ \\
\hline 1 & $.766 \mathrm{a}$ & .548 & .537 & 3327.2017 & .478 & 47.249 & 2 & 115 & .000 \\
\hline
\end{tabular}

a. Predictors: (Constant), GDP, CPI.

Source: author calculations using SPSS 20.

Still, the Model Summary table shows that our model could be improved in order to have better values of $\mathrm{R}$ and $\mathrm{R}$ square by adding other institutional variables in equation beside corruption like democracy, government stability, law and order, democracy and the quality of bureaucracy.

The qualitative assessment of the impact of corruption on FDI for the countries analysed confirms the results of empirical analysis.

Figure 1. The evolution of FDI and CPI for Georgia

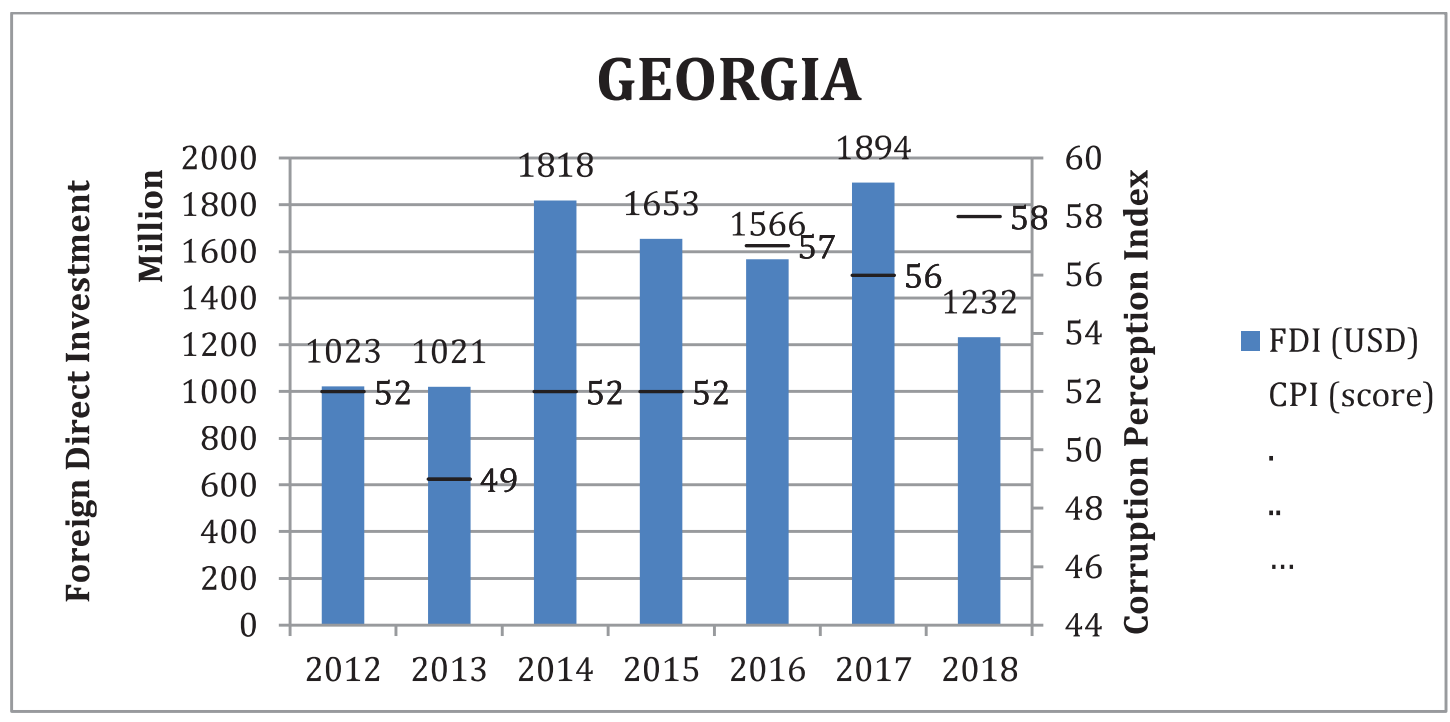

Source: UNCTAD and Transparency International

Still, we must mention that the least corrupt country of Caucasia is Georgia with a CPI score higher than 55. The highest level of FDI inflows is attracted by Georgian even if the CPI index shows the lowest levels for the countries analysed. These results can be explained by the active policy promoted by the Georgian government for attracting foreign direct investors (mainly fiscal incentives). Georgia stands alone in the group. We can see that in Georgia even if the effect of the economic crises reflects in the levels of FDI inflows, from 2012 to 2018 the perceived corruption is constantly improving. 
Figure 2. The evolution of FDI and CPI for Azerbaijan

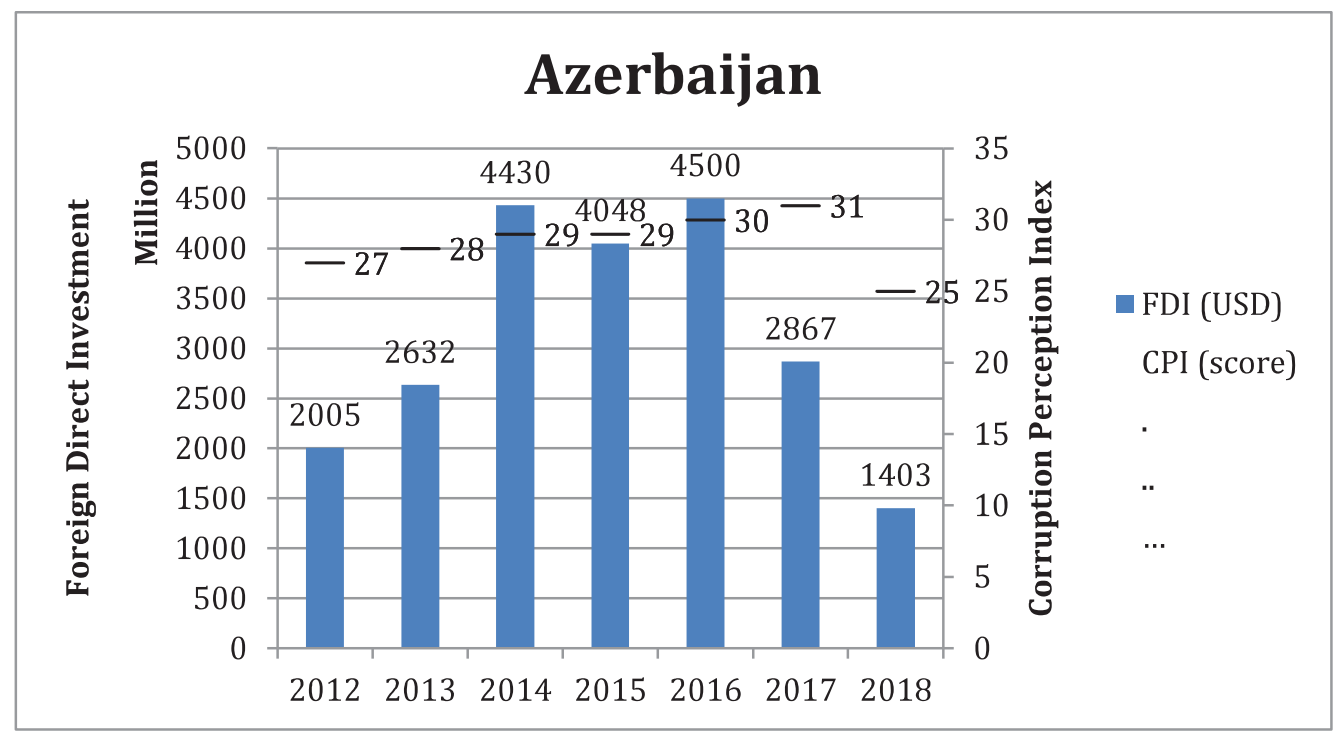

Source: UNCTAD and Transparency International

First of all, figure 2 shows that Azerbaijan is considered a highly corrupt country. The evolution of perceived corruption improved over time. Regarding to FDI inflows attracted by Azerbaijan, we can observe that is correlated with the evolution of CPI index. The decrease of the measure of corruption (meaning a rise in the perceived corruption (0-highly corrupted to 100 - very clean)), correspond with lower values of FDI inflows in the next year.

Figure 3. The evolution of FDI and CPI for Armenia

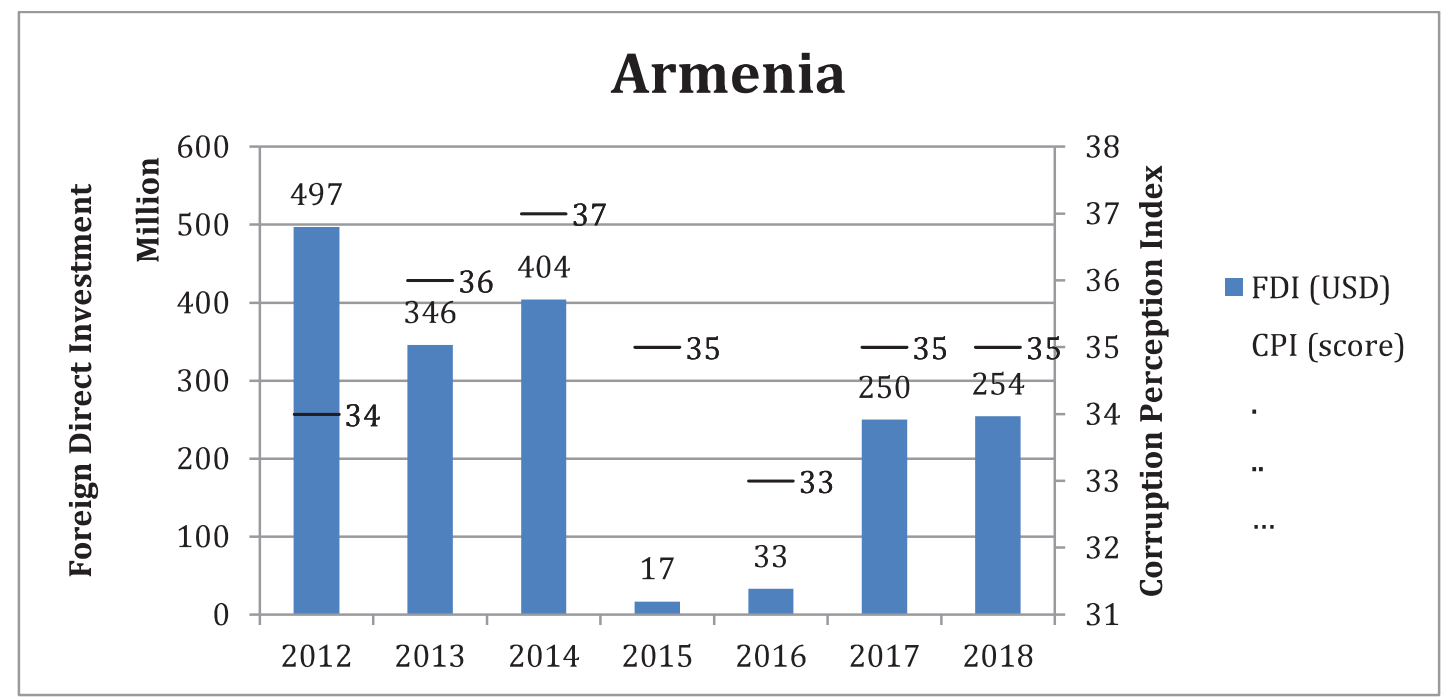

Source: UNCTAD and Transparency International

Analysing Georgia, Azerbaijan and Armenia we can observe a mainly indirect relation between foreign direct investments and CPI. Azerbaijan and Armenia have 
An Assessment of Corruption's Impact on the Inflow of Foreign Direct Investment...

a particularly trend of the perceived corruption showing the same evolution. After a period of reforms and concrete efforts in reducing corruption, the emergence of the economic crises marked decreases in the levels of corruption perception index and in FDI inflows.

\section{Conclusion}

FDI receiving host countries expect foreign investments to support, technological and employment progress, competitiveness and economic growth. For Georgia, Azerbaijan and Armenia there was also improve efficiency and an expectation regarding the transition process. But the transition from a centralized economy to market-orientated states showed many challenges handled by each country analysed in its own way. One of these challenges for these countries proved to be the emergence of systematic corruption.

Our analysis focuses on the impact of corruption on foreign direct investment flows attracted by Georgia, Azerbaijan and Armenia. Our results show a significant negative relation between corruption and FDI and GDP using as determinants the CPI index and between GDP and FDI a mild positive significant relation. These results can be explained by the fact that after a complex analysis of the business environment the foreign direct investors decide to invest or not. So, we can affirm that for Georgia, Azerbaijan and Armenia the impact of market potential, although high is diminished by the other factors related to stability and predictability of the regulatory system. Our analysis shows that regarding the perceived corruption are hasty necessary reforms of public administration in order to reduce all the forms of corruption and bribery. Armenia needs coherent reforms to reduce corruption, as a highly corrupted country after Transparency International methodology, and in the same time increase the country locational attractiveness for foreign direct investors.

Summing up, it can be concluded that generally corruption affects the investment attractiveness of the country, but it is not the major factor affecting the FDI inflow.

\section{BIBLIOGRAPHY}

Alemu M.A., Effects of Corruption on FDI Inflow in Asian Economies, "Seoul Journal of Economics" 2012, vol. 25 , no. 4 .

Al-Sadiq, A., The Effects of Corruption on FDI Inflows, "Cato Journal” 2009, vol. 29, no. 2.

Amarandei C.M., Corruption and Foreign Direct Investment. Evidence from Central and Eastern European States, http://www.ceswp.uaic.ro/articles/CESWP2013_V3_AMA.pdf.

Amundsen I., Political Corruption: An Introduction to the Issues,. Chr. Michelsen Institute Development Studies and Human Rights, Working Paper, 1999. 
Aparna M., Foreign Direct Investment, Corruption, and Democracy, "Applied Economics" 2011, vol. 45, no. 8.

Balboa J., Medalla, M. E., Anti-Corruption and Governance: The Philippine Experience. APEC Study Center Consortium Conference 2006, 1-28, Ho Chi Minh City, Viet Nam.

Brada J.C., Corruption and Multinational Investment: Micro-foundations and Empirical evidence, "World Economic Journal" 2014.

Castro C., Nunes, P., Does Corruption Inhibit Foreign Direct Investment?, "Revista de Ciencia Politica" 2013, vol. 51, no. 1 .

Cuervo-Cazurra A., Who Cares about Corruption?, "Journal of International Business Studies" 2006, vol. 37 , no. 6 .

Dahlström T., Johnson A., Bureaucratic Corruption, MNEs and FDI “Jönköping International Business School (JIBS)" 2007, paper no. 82.

Habib M., Zurawicki L. Corruption and Foreign Direct Investment, "Journal of International Business Studies" 2002, vol. 33, no. 2.

Jones J., Wren C., Foreign Direct Investment and the Regional Economy, Ashgate Publishing, Ltd. 2012.

Kendall T., Zhou Y., The Impact of Corruption on FDI 2009, https://editorialex press.com/cgibin/conference/download.cgi?db_name=serc2009\&paper_id=212.

Macrae J., Underdevelopment and the Economics of Corruption: A Game Theory Approach, "World Development" 1982, vol. 10, no. 8.

Quazi M.R., Corruption and Foreign Direct Investment in East Asia and South Asia: An Econometric Study, "International Journal of Economics and Financial Issues" 2014, vol. 4, no. 2.

Quazi R., Vemuri V., Soliman M., Impact of Corruption on Foreign Direct Investment in Africa, "International Business Research" 2014, vol. 7, no. 4.

Runde D. F., The cost of corruption, 2014, https://csis-prod.s3.amazonaws.com/s3fs- public/legacy_ files/files/publication/140204_Hameed_CostsOfCorruption_Web.pdf.

Teixeira C.A.A., Guimarães L., Corruption and FDI: Does the Use of Distinct Proxies for Corruption Matter?, "Journal of African Business" 2015, vol. 16, no. 1-2.

Woo J.Y., The Impact of Corruption on a Country's FDI attractiveness; A Panel Data Analysis, 19842004", "Journal of International and Area Studies" 2010, vol. 17, no. 2.

Worldbank, Combating Fraud and Corruption, 2017, www.ifc.org/wps/wcm/connect/Topics ExtContent/IFCExternal CorporateSite/ACHome/. 